\title{
Gut microbiota, probiotics, prebiotics and bone health: a review
}

\author{
Nan Shang and Jianping $\mathrm{Wu}^{*}$ \\ Department of Agricultural, Food and Nutritional Science, University of Alberta, Edmonton, AB, Canada \\ ${ }^{*}$ Corresponding author: Dr. Jianping Wu, 4-10 Ag/For Centre, Edmonton, AB, Canada T6G 2P5. Tel: (780) 492-6885; Fax: (780) 492- \\ 4265; E-mail: jwu3@ualberta.ca \\ DOI: $10.31665 /$ JFB.2018.3153 \\ Received: September 02, 2018; Revised received \& accepted: September 11, 2018 \\ Citation: Shang, N., and Wu, J. (2018). Gut microbiota, probiotics, prebiotics and bone health: a review. J. Food Bioact. 3: $101-110$.
}

\begin{abstract}
Gut microbiota is widely accepted to play a crucial role on host health via the regulation of many physiological functions, including metabolism, nutrition, pathogen resistance, and immune function. Over the last decades, accumulating evidence has also pinpointed a role for gut microbiota on bone metabolism and the development of metabolic bone diseases, such as osteoporosis. Emerging evidence suggests the potential of gut microbiota as a promising target for bone health management. In this contribution, we have examined the available literature to understand the role of gut microbiota on bone metabolism as well as the underlying mechanisms. Furthermore, the application and effectiveness of using probiotics/prebiotics as means to modify gut microbiota and bone health are discussed. In this relation, animal studies and human trails suggest that alternation of gut microbiota composition can exert the activity of bone metabolism and therefore lead to the change of bone quality. It is believed that gut microbiota regulates bone metabolism via host immune system, endocrine system and mineral absorption. Supplementation with probiotics and prebiotics to both animals and humans has demonstrated promising, but sometimes conflicting results, on bone health. Thus, future research is expected to reveal the influence of the variations in age, gender, dose, delivery method, and treatment duration, among others on the probiotics/prebiotics-targeted bone diseases treatment.
\end{abstract}

Keywords: Microbiota; Bone health; Probiotics; Prebiotics; Bone metabolism.

\section{Introduction}

Bone health is critically important to the overall health and quality of life. In addition to forming a protective and supportive framework for the body, bones also provide mobility, and serve as a storehouse for minerals that are vital to the functioning of many other life-sustaining systems (Office of the Surgeon General, 2004). It is a dynamic organ, which is constantly undergoing remodeling to replace or reshape injured or micro-damaged bone and to maintain mechanical loading (Collins et al., 2017; Quach and Britton, 2017). While it has been known for a long time that the gastrointestinal system plays a critical role in maintaining calcium homeostasis and skeletal integrity (Keller and Schinke, 2013), recent studies underscore an emerging role of gut microbiota in regulating bone metabolism (Collins et al., 2017). It is estimated that $>1000$ different microbial species exist in the hu- man gut (Chen et al., 2017). The communication and coevolution between intestinal microbiota and the host provide benefits to both the bacteria and the host in most cases (Quach and Britton, 2017). It is well accepted that a dynamic homeostasis of gut microbiota is critical to host's health and plays a crucial role in many aspects, including metabolism, nutrition, pathogen resistance, and immune function (Collins et al., 2017; Xu et al., 2017). Accumulating evidence has demonstrated that gut microbiota is associated with bone metabolism and a range of inflammatory or metabolic bone diseases (Blanton et al., 2016; Guss et al., 2017; Sjögren et al., 2012; Xu et al., 2017; Yan et al., 2016). Therefore, modification of gut microbiota by probiotics and/or prebiotics supplementation has been proposed as a viable therapeutic strategy to benefit bone health. In this review, we examined the available literature to understand the role of gut microbiota on bone metabolism as well as the underlying mechanisms. Furthermore, the applications and 
effectiveness of using probiotics/prebiotics as means to modify gut microbiota and bone health are discussed.

\section{Bone physiology and osteoporosis}

Bone is always viewed as settled, however, it is a dynamic and living tissue that continuously requires all essential nutrients for growth and maintenance. Throughout life, bone constantly undergoes a cycle named "remodeling", to remove old, microdamaged bone and replace with new, mechanically sound one to preserve its strength (Kini and Nandeesh, 2012). During the remodeling process, at least three types of cell are involved, including bone formation cells osteoblasts and osteocytes, and resorption cells osteoclasts (Rucci, 2008). Bone remodeling is subjected to systemic and local regulation, such as nutritional status, sex hormone status, parathyroid hormone level, and vitamin D status. In healthy condition, the remodeling is in a balance, in which bone formation is equal to bone resorption. However, an imbalance in remodeling can lead to different bone diseases when the formation is either more or less than the resorption.

Osteoporosis is a bone disease mainly caused by increased bone resorption compared to bone formation. It reduces bone strength, bone mass and bone microarchitecture, therefore leading to increased risk of fracture (Nieves, 2005). Although osteoporosis is always considered as an age-related disease, especially for postmenopausal women, it could also happen in children, adolescents and adults since it could be a side-effect of medication use, like glucocorticoid-induced osteoporosis (US Department of Health and Human Services, 2004). Since the main reason for osteoporosis is due to the imbalanced bone remodeling, the medications intended for osteoporosis aim to either stimulatie bone formation such as parathyroid hormone (PTH) therapy, or reduce bone resorption such as bisphosphonates, raloxifene, teriparatide, calcitonin, denosumab, estrogen and menopausal hormone therapy. These medications are effective in preventing bone loss, increasing bone mineral density, and decreasing the risk of fractures, but are unfortunately associated with sever side effects, such as nausea or increased risk of cancer, stoke or cardiovascular disease (Sharif et al., 2011). Recent studies have demonstrated a close relationship between intestinal microbiota and bone metabolism, providing a promise that the intestinal microbiota may serve as a potential therapeutic target for the treatment of osteoporosis.

\section{Association between intestinal microbiota and bone}

The first evidence that indicated the relationship between gut microbiota and bone metabolism was reported by Di Stefano et al. (2001). They reported that the loss of bone mineral density was associated with intestinal bacterial overgrowth (Table 1). This finding were further validated by Stotzer et al. (2003), who observed the reduction of bone mineral density in bacteria overgrown individuals (Table 1). Both studies indicated that overgrowth of gut microbiota could be a risk factor associated with bone loss. However, another study developed with healthy and disabled individual who suffered from bacteria overgrowth gave contradictory results (Mitsui et al., 2005). In this latter study, there was no significant difference in femoral bone mineral density between bacterial overgrowth individuals and the control group (Table 1). However, this result might be due to the disabled condition of all experimental subjects, which led to an extremely low physical activity.

For several decades, germ-free animals have been used to study the interaction between the microbiota and host physiologies (AlAsmakh and Zadjali, 2015). Sjögren et al. (2012) first studied the connection between gut microbiota and bone health with germfree mice model (Table 1). In their study, germ-free mice showed a higher trabecular volume bone mineral density and improved histomorphologic indices, compared with conventionally raised mice (Sjögren et al., 2012). Meanwhile, germ-free mice showed decreased frequency of $\mathrm{CD} 4^{+} \mathrm{T}$ cells and $\mathrm{CD} 11 \mathrm{~b}^{+} / \mathrm{GR} 1$ osteoclast precursor cells in bone marrow as well as the decreased expression of inflammatory cytokines in bone marrow, suggesting gut microbiota might influence bone health by inhibiting osteoclastogenesis (Sjögren et al., 2012). More importantly, all these changes were normalized when germ-free mice were recolonized by a normal gut microbiota, which further confirmed that gut microbiota is the main factor responsible for the increase of bone mineral density in the germ-free mice (Sjögren et al., 2012). However, some conflicting findings have also been published. Schwarzer et al. (2016) noticed a significantly reduced femur length, cortical thickness, cortical bone fraction, and the trabecular fraction of the femur in germ-free mice. The different results from these studies may attribute to the different genetic profiles of the C57BL/6J mice (used in Sjogren et al. study) and the BALB/c mice (used in Schwarzer et al., study), as well as the gender difference (female mice used in Sjorgren et al. study and male mice in Schwarzer et al. study). Furthermore, the influence of gut microbiota on bone metabolism has been found to be time-dependent. Microbial recolonization in germ-free mice induced an acute decrease in bone mass, while an increase in bone formation and bone growth plate activity after long-term colonization (Yan et al., 2016). This suggests that the influence of gut microbiota on bone health is a long-term invention. In addition to the duration, it is interesting that transplanting microbiota from healthy and undernourished children into germ-free mice showed varied femoral phenotypes (Blanton et al., 2016). Although the sample size is not big enough, their results provided evidence for microbiota-dependent regulation of bone morphology, with the effects being influenced by the age and nutritional status of the donor (Blanton et al., 2016).

Antibiotics treatment has been well studied for its ability to change the composition of the gut microbiota. Thus, antibiotics intervention is also used to investigate the relations between gut microbiota and bone processing, in addition to using germ-free animals (Table 1). Cox et al. (2014) studied the changes of bone condition when gut microbiota was disrupted by low-dose antibiotic exposure. Low dose penicillin (LDP) was delivered via drinking water to both male and female mice (Cox et al., 2014). Interestingly, LDP treated male mice showed decreased bone mineral density, while female mice showed the opposite effect (Cox et al., 2014). This study also proposed that the influence of gut microbiota on bone tissue was gender-dependent (Table 1). Several additional antibiotics studies have supported these findings and suggested that gut microbiota may be responsible for bone growth through several regulation pathways (Table 1).

\section{Potential mechanisms of gut microbiota on bone metabolism}

Numerous studies have revealed that gut microbiota can regulate bone metabolism, but understanding of the regulatory role of gut microbiota on bone metabolism is still far from clear. However, it is obvious that not a single mechanism can explain this function. Multiple approaches through which gut microbiota may regulate bone metabolism have been proposed, including actions on the immune system, endocrine system, and calcium absorption (Figure 
Table 1. Current study on gut microbiota and bone health

\begin{tabular}{|c|c|c|c|}
\hline Research model & Treatment & Outcomes & Reference \\
\hline \multicolumn{4}{|l|}{ Human study } \\
\hline $\begin{array}{l}\text { Human } \\
\text { Predispose to } \\
\text { bacterial overgrowth }\end{array}$ & $\mathrm{N} / \mathrm{A}$ & $\begin{array}{l}\text { Low BMD in lumbar and femoral } \\
\text { High bone loss at lumbar and femoral } \\
\text { Small intestine bacterial overgrowth is a cofactor } \\
\text { in the development of metabolic bone disease }\end{array}$ & $\begin{array}{l}\text { Di Stefano } \\
\text { et al., } 2001\end{array}$ \\
\hline $\begin{array}{l}\text { Human } \\
\text { Predispose to } \\
\text { bacterial overgrowth }\end{array}$ & $\mathrm{N} / \mathrm{A}$ & $\begin{array}{l}\text { Low BMD in lumbar and femoral } \\
43 \% \text { of the patients had had fractures }\end{array}$ & $\begin{array}{l}\text { Stotzer et } \\
\text { al., } 2003\end{array}$ \\
\hline $\begin{array}{l}\text { Human } \\
\quad \text { Small bowel } \\
\text { bacterial overgrowth } \\
\text { (SBBO) }\end{array}$ & N/A & $\begin{array}{l}\text { Significant difference in femoral BMD } \\
\text { between healthy control and SBBO- } \\
\text { negative group and SBBO-positive group } \\
\text { No significant difference in femoral } \\
\text { BMD between SBBO-positive group } \\
\text { and SBBO-negative group }\end{array}$ & $\begin{array}{l}\text { Mitsui et } \\
\text { al., } 2005\end{array}$ \\
\hline
\end{tabular}

Germ-free Animal Study and Antibiotics Intervention Study

\begin{tabular}{|c|c|c|c|}
\hline $\begin{array}{l}\text { C57B16/J mice } \\
\text { Female germ-free }\end{array}$ & N/A & $\begin{array}{l}\text { Increased bone mass in germ-free mice } \\
\text { associated with reduced number of osteoclasts } \\
\text { Colonization of germ-free mice with normal } \\
\text { gut microbiota normalizes bone mass }\end{array}$ & $\begin{array}{l}\text { Sjögren et } \\
\text { al., } 2012\end{array}$ \\
\hline $\begin{array}{l}\text { C57BL/6J mice } \\
\text { Male and female }\end{array}$ & $\begin{array}{l}\text { Exposed to low-dose penicillin } \\
\text { post-weaning (LDP-w) }\end{array}$ & $\begin{array}{l}\text { LDP-w male mice showed decreased } \\
\text { bone mineral content } \\
\text { LDP-w female mice showed elevated } \\
\text { bone mineral density }\end{array}$ & $\begin{array}{l}\text { Cox et al., } \\
2014\end{array}$ \\
\hline $\begin{array}{l}\text { C57BL/6J mice } \\
\text { Male and female }\end{array}$ & $\begin{array}{l}\text { Pulsed antibiotic treatemetn (PAT) with } \\
\text { 1) amoxicillin; 2) tylosin; 3) sequential } \\
\text { courses of tylosin, amoxicillin and tylosin }\end{array}$ & $\begin{array}{l}\text { PAT accelerated bone growth and caused } \\
\text { progressive changes in gut microbiome diversity, } \\
\text { population structure and metagenomic content }\end{array}$ & $\begin{array}{l}\text { Nobel et } \\
\text { al., } 2015\end{array}$ \\
\hline $\begin{array}{l}\text { BALB/c mice } \\
\text { Male germ-free }\end{array}$ & $\begin{array}{l}\text { Lactobacillus. Plantarum }{ }^{\mathrm{WJL}} \text { and } \\
\text { L. plantarum }{ }^{\mathrm{NIZO}} \text { pl77 }^{\text {were gavage }} \\
\text { to } 8 \text {-week-old mice to develop } \\
\text { Lactobacillus-monocolonized mice }\end{array}$ & $\begin{array}{l}\text { Reduced femur length, cortical thickness, } \\
\text { cortical bone fraction, and the trabecular } \\
\text { fraction of the femur in germ-free mice } \\
\text { Lactobacilli promoted juvenile growth }\end{array}$ & $\begin{array}{l}\text { Schwarzer } \\
\text { et al., } 2016\end{array}$ \\
\hline $\begin{array}{l}\text { C57BL/6 mice } \\
\text { Male germ-free }\end{array}$ & $\begin{array}{l}\text { Microbiota from } 6 \text {-month/8-month } \\
\text { healthy or undernourished infants } \\
\text { were gavage to germ-free mice }\end{array}$ & $\begin{array}{l}\text { Higher femoral cortical ratios of bone volume } \\
\text { to tissue volume (BV/TV) and volumetric } \\
\text { bone mineral density (vBMD) in recipients } \\
\text { of undernourished donor gut microbiota } \\
\text { Mice colonized with 6-month old donor } \\
\text { microbiota had higher BMD, BV/TV, } \\
\text { trabecular connectivity and number } \\
\text { and lower trabecular spacing }\end{array}$ & $\begin{array}{l}\text { Blanton et } \\
\text { al., } 2016\end{array}$ \\
\hline $\begin{array}{l}\text { CB6F1 mice } \\
\text { Male germ-free }\end{array}$ & $\begin{array}{l}\text { Microbiota from 3-month-old male CB6F1 } \\
\text { SPF mice were gavage to germ-free mice }\end{array}$ & $\begin{array}{l}\text { Increased both formation and resorption } \\
\text { in microbiota colonized group } \\
\text { Acutely reduced bone loss after colonization } \\
\text { Increased bone formation, growth plate } \\
\text { activity and insulin-like growth factor 1(IGF- } \\
\text { 1) showed in long-term colonization }\end{array}$ & $\begin{array}{l}\text { Yan et al., } \\
2016\end{array}$ \\
\hline $\begin{array}{l}\text { C57BL6/J mice } \\
\text { Female germ-free }\end{array}$ & $\begin{array}{l}\text { Microbiota from 10-week-old C57BL6 } \\
\text { mice were gavage to germ-free mice } \\
\text { GnRH agonists Lupron Depot } \\
\text { was administered to induce } \\
\text { sex steroid deficiency } \\
\text { Sex steroid deficiency mice treated with } \\
\text { Lactobacillus rhamnosus GG, commercial } \\
\text { probiotic supplement VSL\#3, Escherichia } \\
\text { coli and a mutant L. rhamnosus GG }\end{array}$ & $\begin{array}{l}\text { Germ-free mice failed to increase } \\
\text { sex steroid deficiency-induced bone } \\
\text { resorption and trabecular bone loss } \\
\text { Probiotic treatment reduced bone marrow } \\
\text { inflammation and protected against bone loss } \\
\text { nonprobiotic (E. coli and mutant L. rhamnosus } \\
\text { GG) treatment showed no protective effect }\end{array}$ & $\begin{array}{l}\text { Li et al., } \\
2016\end{array}$ \\
\hline $\begin{array}{l}\text { Swiss Wester mice } \\
\text { C57BL/6 mice } \\
\text { Germ-free }\end{array}$ & $\begin{array}{l}\text { Distinct microbiotas that originated } \\
\text { from human or mice were } \\
\text { gavage to germ-free mice }\end{array}$ & $\begin{array}{l}\text { No significantly change between germ- } \\
\text { free group and colonized group }\end{array}$ & $\begin{array}{l}\text { Quach et } \\
\text { al., } 2018\end{array}$ \\
\hline
\end{tabular}




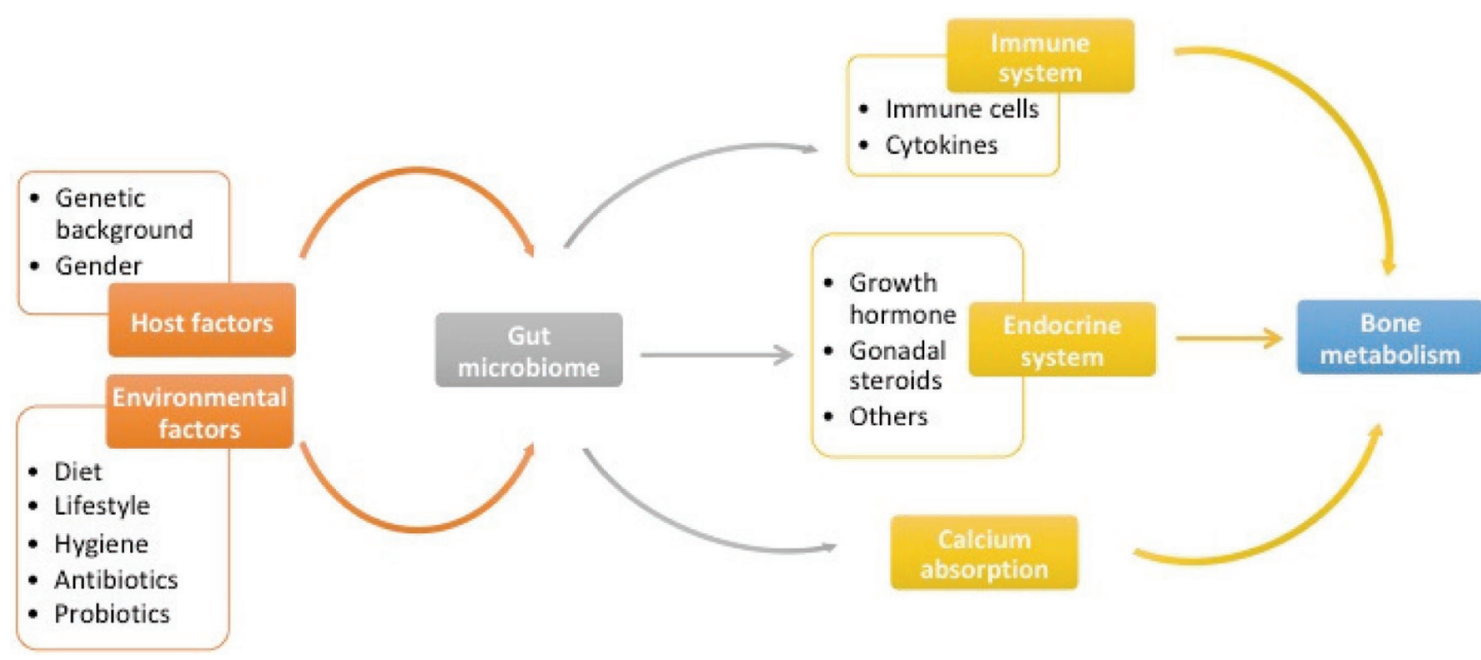

Figure 1. The Sketch of the regulators of gut microbiome and the relationship between gut microbiome and bone metabolism. Both host and environment affects the individual gut microbiota and further regulate bone metabolism via immune system, endocrine system and calcium absorption. (Modified according to Xu et al., 2017).

1). The current findings related to possible mechanisms involved are outlined below.

\subsection{Gut microbiota regulates bone metabolism through im- mune system}

The presence of a close interrelationship between immune system and bone metabolism has led to coining the term "osteoimmunology", which highlights the role of immune-related factors in modulating bone remodeling (Crotti et al., 2015; Xu et al., 2017; Zupan et al.,, 2013). It has been well documented that the osteoclasts, originating from monocytic precursors in bone marrow, can interact and be regulated by immune cells ( $\mathrm{B}$ and $\mathrm{T}$ cells) and immune stimulating factors (RANKL, TNF- $\alpha$, IL-1, IL-6) (Lorenzo et al., 2008). Especially for the differentiation and maturation, the RANKL (receptor activator NF kappa B ligand)-RANK (receptor activator NF kappa B)-OPG (osteoprotegerin) axis and immunoreceptor tyrosine-based activation motif (ITAM) pathway play key roles in bone turnover and bone diseases (Crotti et al., 2015; Kim et al., 2002; Xu et al., 2017). Characterization of the functions of RANKL and its receptors (RANKL and OPG) have contributed significantly to the emergence of osteoimmunology, specifically with respect to examining the interplay between the active immunity and maintenance of bone homeostasis (Lorenzo et al., 2008; Teitelbaum, 2000; Walsh et al., 2006). In addition to RANKL, other immune stimulating factors, such as tumor necrosis factor alpha (TNF $\alpha$ ), interleukin-6 (IL-6), interleukin-11 (IL-11), and leukemia inhibitory factor (LIF), play crucial roles in osteoimmunology and regulated bone homeostasis. For example, bone loss induced by estrogen deficiency is due to the increased differentiation and activity of osteoclasts in part promoted by increased inflammation and activation of immune cells (Quach and Britton, 2017).

Recently, it has been widely recognized that gut microbiota can interact with the host immune system and further influence host health (Geuking et al., 2014; Palm, de Zoete and Flavell, 2015; Xu et al., 2017). Gut microbiota can regulate not only the local intestinal immune system, but can also regulate the immune response and hematopoiesis at distant sites including the bone marrow (Wu and $\mathrm{Wu}, 2012$ ). The hypothesis that gut microbiota regulates bone metabolism through the immune system has been investigated and proven by some animal studies. In the study of Sjögren et al. (2012), germ-free mice showed decreased expression of proinlammatory cytokines TNF $\alpha$ and IL-6, fewer frequency of CD4 $\mathrm{T}$ cells and reduced osteocalst/precursor cells in bone marrow (Sjögren et al., 2012). These results suggested that gut microbiota could modulate immune system and inhibit osteoclastic bone resorption. Studies also indicated that autoimmune arthritis was strongly attenuated in the $\mathrm{K} / \mathrm{BxN}$ mouse model under germ-free condition, accompanied by reductions in serum autoantibody titers, splenic autoantibody-secreting cells, germinal centers and the splenic T helper cell population, suggesting the regulatory role of gut microbiota on bone metabolism by altering host immune status (Wu et al., 2010). Taken together, although further studies are still needed to identify the species that can lead to the change of immune system, it has been accepted that immune system is at least partly responsible for gut microbiota regulated bone metabolism.

\subsection{Gut microbiota regulates bone metabolism through the en- docrine system}

Since the development of bone loss is highly impacted by crosstalk between immune cells and monocytes that can differentiate into osteoclasts, early focus has been placed on the dysregulation of osteoclastogenesis by the immune system. Other studies have also investigated the role of endocrine system as another important regulator of bone metabolism. Gut microbiota is currently considered as a novel "endocrine organ", as it can engage in an interplay between the endocrine system and hormone level, further influencing host health status (Neuman et al., 2015; Sudo, 2014; Xu et al., 2017).

4.2.1. Gut microbiota regulates bone metabolism by growth hormone

Gut microbiota are capable of dynamically modulating circulating IGF-1 in the host, with the majority of data suggesting that microbiota could induce host IGF-1 synthesis to influence growth (Yan 
and Charles, 2018). This study found the increase of bone mass in long-term colonized germ-free mice was associated with the increase of serum IGF-1, in response to microbial colonization (Yan et al., 2016). Antibiotic treatment of conventional mice showed inhibition in bone formation along with decreased serum IGF-1 in the same study. Interestingly, antibiotic-treated mice supplemented with short chain fatty acids (SCFAs), one of the microbiota-derived metabolites, significantly restored bone mass with increased IGF-1 level (Yan et al., 2016). According to this study, gut microbiota could provide a net anabolic stimulus to the skeleton, which is likely mediated by IGF-1. Thus, manipulation of the microbiota or its metabolite may afford opportunities to optimize bone health and growth.

\subsubsection{Gut microbiota regulates bone metabolism by gonadal steroids}

Gonadal steroids, including estrogen and androgen, play key roles in the regulation of bone mass and turnover in bone metabolism (Imai et al., 2009; Leder, 2007; Syed and Khosla, 2005; Xu et al., 2017). Especially for estrogen, the decrease of estrogen level is a major factor that contributes to postmenopausal osteoporosis risk. During menopause, a variety of negative health outcomes may occur due to a decline of circulating estrogen, especially a rapid drop of bone mass (Baker et al., 2017). The hormone therapy and selective estrogen receptor modulators (SERMs) are both current osteoporosis drugs targeting estrogen deficiency.

More recently, intestinal microbiota which is capable of metabolizing estrogens were defined as "estrobolome" (Baker et al., 2017). In the human body, estrogens circulate in the blood in the free or protein-bound form and exert diverse biological effects (Kwa et al., 2016). However, only the free form of estrogen is activated, while the conjugated estrogens will be eliminated and excreted in the urine or feces (Kwa et al., 2016). A current study found that the conjugated estrogen can be deconjugated by estrobolome and reabsorbed into the circulation (Kwa et al., 2016). Some bacterial species have been identified with $\beta$-glucuronidase activity that might potentially increase intestinal reabsorption of estrogens (Kwa et al., 2016). However, further studies are needed to validate and confirm this postulation.

It is also known that gut microbiota may influence the absorption and metabolism of phytoestrogens, such as isoflavones and lignans. Many phytoestrogens can be hydrolyzed by intestinal microflora such as lactobacillus spp. and bifidobacterium spp. and result in an active formation, which could increase their bioavailability (Xu et al., 1995). For example, isoflavones can be converted into equol, which has more estrogenic effects, by specific gut microorganisms such as bifidobacterium animalis and enterobacteriaceae strains (Guadamuro et al., 2015; Vázquez et al., 2017; Yuan et al., 2007). These results suggest that supplementation with specific probiotics and phytoestrogen together might be beneficial for estrogen deficiency-induced osteoporosis.

\subsubsection{Gut microbiota regulates bone metabolism by other hor- mones}

Althought gut microibata plays major role in growth hormone and sex hormone regulated bone metabolism, the interactions among gut microbiota, endocrine system and bone metabolism are complex. Other hormones may also facilitate the bone metabolism, such as PTH. PTH plays a central role in regulating calcium-phosphate metabolism. A prolonged hypersecretion of PTH leads to in- creased bone resorption, while administered at a low and intermittent dose will be able to exert positive effects on bone volume and microarchitecture (Lombardi et al., 2011). Intermittent administration of PTH increased local IGF-1 production and activated IGF-1 signaling pathways in bone and therefore promoted bone formation (Wang et al., 2013). In a human trial, Lactobacillus helveticus fermented milk supplementation increased serum calcium levels and reduced serum PTH level in postmenopausal woman (Narva et al., 2004b). Although the long-term effect of this on bone health was not measured, the changes in calcium and PTH suggested an influence of specific bacteria on bone health by affecting PTH.

It was recently discovered that gut microbiota might have important effects on the nervous system through regulation of the synthesis of hormones and neurotransmitters such as serotonin (5-hydroxytryptamine, 5-HT). It has been reported that both osteoblasts and osteocytes contain 5-HT receptors, and the circulating 5-HT plays a key role in regulating bone formation and skeleton mass (Mödder et al., 2010; Yadav et al., 2008). Indigenous sporeforming bacteria $(\mathrm{Sp})$ from both mouse and human microbiota promoted 5-HT biosynthesis from colonic enterochromaffin cells (ECs), which supply 5-HT to the mucosa, lumen and circulating platelets (Yano et al., 2015). However, there is still a controversy on the role of 5-HT on bone health. Yadav et al. (2008) suggested that peripheral 5-HT produced in gut was a major negative regulator of osteoblast proliferation. However, Cui et al. (2011) reported that bone density was not affected by 5 -HT stimulation in mice. Thus, it is important to develop clinical and experimental studies with different models to investigate the effect of 5-HT on bone health as well as its interaction with gut microbiota.

\subsection{Gut microbiota regulates bone metabolism by influencing calcium absorption}

It is well documented that gut microbiota can affect the absorption of skeletal development-related nutrient such as calcium and vitamin D (Xu et al., 2017). Calcium, the dominant mineral component in bones, is essential for bone health. In addition, vitamin $\mathrm{D}$ could regulate the intestinal calcium absorption and stimulate bone resorption to maintain serum calcium concentration ( $\mathrm{Su}$ nyecz, 2008). Thus, either dietary calcium deprivation or vitamin D deficiency may cause bone loss and finally lead to osteoporosis (Morris et al., 2010; Xu et al., 2017).

The gut microbiota contribute to bone health by either affecting calcium intake or regulating endocrine vitamin $\mathrm{D}$. On the one hand, the gut microbiota could promote calcium intake rates. Normal calcium intake rates in adults are $~ 30-35 \%$ (Sheikh et al., 1990; Xu et al., 2017); these levels can be increased by probiotics, prebiotics, and synbiotics (Scholz-Ahrens et al., 2007; Xu et al., 2017). For example, enhanced calcium absorption was observed in healthy male rats treated with galacooligosaccharides (GOS) or inulin (Chonan et al., 2002), healthy female rats treated with polydextrose for 4 weeks (Legette et al., 2012) and healthy female mice treated with fructose and inulin for 6 weeks (García-Vieyra et al., 2014). Therefore, in healthy condition, the gut microbiota could enhance the calcium absorption to improve the bone quality and protect against osteoporosis in the future. Moreover, gut microbiota could also stimulate calcium absorption in individuals who already developed osteoporosis and help to attenuate bone loss. In estrogen deficient ovariectomized (OVX) rats, both inulin and fructooligosaccharides (FOS) increased calcium absorption and bone mineral density (Zafar et al., 2004). On the other hand, gut microbiota also contribute to calcium resorption by regulating the endocrine vitamin D (Bora et al., 2018). Supplementation of 
difructose anhydride III (DFAIII, at a dose of $15 \mathrm{~g} / \mathrm{kg}$ for 4 weeks) in a vitamin D-deficient diet to OVX rat significantly attenuated vitamin D deficiency induced suppression of calcium absorption and decrease of femoral calcium (Mitamura and Hara, 2006).

\section{Application of probiotics and prebiotics in bone health man- agement}

With the development knowledge of gut microbiota and bone health, probiotics and prebiotics have been introduced into bone health management because of their modification role on host gut microbiota. A number of studies have investigated the application of probiotics and prebiotics to prevent osteoporotic bone loss (Table 2).

\subsection{The applications of probiotics}

Probiotics refer to the live microorganisms that when administered in adequate amount will confer a health benefit on the host (Schepper et al., 2017). Stability of the intestinal microbiota composition is a critical regulator of intestinal homeostasis throughout life, from new born to adulthood. Blanton et al. (2016) found that germfree mice colonized gut microbiota from undernourished children displayed reduced growth, altered bone morphology and metabolic dysfunction compared to mice populated with healthy microbiota. Interestingly, adding bacterial Ruminococcus gnavus and Clostridium symbiosum to the microbiota from undernourished children ameliorated growth abnormalities in the mice, suggesting supplementation with probiotics can alter microbiota composition and regulate growth (Blanton et al., 2016). In support of this finding, Schwarzer et al. (2016) reported that undernourished mice supplemented with probiotic Lactobacillus plantarum are able to maintain normal growth rates, especially the under-nutrition suppressed bone growth. Probiotics were also showed to influence the secretion of growth hormones from endocrine system and thus regulate growth. Germ-free mice showed significantly decreased $\mathrm{GH}$ and IGF-1 compared to wild type mice, while supplementation with $L$. plantarum brought IGF-1 back to wild type level (Schwarzer et al., 2016). It seems probiotics may contribute to bone health via influencing intestinal condition in different ways. In the study of McCabe et al. (2013), healthy male mice were treated with Lactobacillus reutieri ATCC 6475, a candidate probiotic with anti-TNF $\alpha$ activity. Supplementation with $L$. reutieri enhanced bone density associated with suppressed intestinal TNF $\alpha$, suggesting the effects of probiotics on preventing inflammation induced bone loss (McCabe et al., 2013). Unfortunately, the decreased intestinal inflammation and increased bone density only showed in healthy male but not in female mice, suggesting the effect was gender specific (McCabe et al., 2013). The authors ascribed the gender dependence to different estrogen and/or progesterone sensitive pathways in response to the bacterium supplementation (McCabe et al., 2013). Recent studies also examined the potential effects of probiotic treatment during osteoporosis, especially in the estrogen deficiency OVX model. While McCabe et al. (2013) previously noted that healthy female mice showed no significant changes in response to L.reuteri, $L$. reuteri supplementation could prevent OVX-induced bone loss in female mice, suggesting that $L$. reuteri could be used for preventing estrogen-induced osteoporosis in postmenopausal women. These findings were confirmed by others using similar probiotics (Table 2). Ohlsson et al. (2014) also found L. paracasei could prevent OVX-induced cortical bone loss and bone resorption.
In addition to direct supplementation with bacterium, administration with food products fermented by probiotics may represent a better solution. Fermented foods are an important part of diet in many cultures. Recent studies examined the effects of fermentation products on the basis of probiotics. OVX rats fed with Lactobacillus-fermented soy skim milk for 8 weeks showed significant increase in trabecular bone volume and numbers, suggesting the fermentation product has similar potential as Lactobacillus to attenuate bone loss in OVX mice and lower the risk of osteoporosis (Chiang and Pan, 2011). Narva et al. (2004a) also confirmed this finding by supplementing $L$. helveticus-fermented milk to growing rats, and found increased bone mineral density and bone mineral content after long-term feeding. Interestingly, L. helveticusfermented milk also showed to increase bone mineral content in spontaneously hypertensive rats due to better calcium availability (Narva et al., 2004a), suggesting its potential on preventing hypertension-associated bone loss. Based on the knowledge on animals, a human study was also performed. Narva et al. (2004b) further studied the effect of $L$. helveticus-fermented milk on calcium metabolism and bone resorption in postmenopausal women. The fermented milk showed reduction in PTH and increase in serum calcium compared to the control group, suggesting its positive effects on calcium metabolism (Narva et al., 2004b). However, this study lacks direct evidence in bone quality measurement.

\subsection{The applications of prebiotics}

Prebiotics are defined as "non-digestible food ingredients that selectively stimulate the growth and/or activity of bacterial species as already established in colon, and thus improve host health" (Whisner and Weaver, 2017). While any nutrient that enters the large intestine may have prebiotic effects, the majority of known prebiotic are carbohydrates. Specifically, oligosaccharides such as inulin-type fructans and galactooligosaccharides (GOS) are well supported for their prebiotic effects on microbial composition primarily through increased proportions of Bifidobacterium and Lactobacillus (Whisner and Weaver, 2017). Thus, supplementation with prebiotics could provide fermentation substrates of gut microbiota, and improve the microbiota composition, which will finally benefit for host health.

Non-digestible oligosaccharides (NDOs) are currently regarded as the most promising prebiotics for bone health, including GOS, fructooligosaccharides (FOS), oligofructose, and inulin (Whisner and Weaver, 2017). Fructooligosaccharides (FOS) has been supplemented to both Korean and Chinese postmenopausal women to investigate its effects on preventing postmenopausal caused osteoporosis (Kim et al., 2004; Kruger et al., 2016). In both studies, FOS showed effects on changing bone biomarkers, such as alkaline phosphatase activity and calcium absorption. GOS and inulin supplementation to postmenopausal woman also showed increase in calcium absorption (van den Heuvel et al. , 2000). Furthermore, some studies have tested the effectiveness of prebiotics on infants or adolescent. GOS (Hicks et al., 2012), polydextrose (PDX) (Hicks et al., 2012) and inulin (Yap et al., 2005) have been supplemented to healthy infants, respectively. However, addition of GOS and PDX did not improve calcium absorption (Hicks et al., 2012), while inulin increased mineral absorption and retention (Yap et al., 2005). Similar conflicting results have been observed in adolescent. In the study of Whisner et al. (2013), adolescent girls consumed GOS showed greater increase in calcium absorption (Whisner et al., 2013). In another study, girls and boys (age 9-13 years) consumed inulin showed greater whole-body bone mineral density and bone mineral content after 12 months (Holloway et al., 
Table 2. current studies on probiotics/prebiotics and bone health

\begin{tabular}{|c|c|c|c|}
\hline Research model & Treatment & Outcomes & Reference \\
\hline \multicolumn{4}{|l|}{ Probiotics } \\
\hline $\begin{array}{l}\text { C57B1/6 mice } \\
\text { Male and female }\end{array}$ & $\begin{array}{l}\text { Treated with Lactobacillus } \\
\text { reuteri ATCC PTA } 6475\end{array}$ & $\begin{array}{l}\text { L. reuteri } 6475 \text { treatment increased male trabecular } \\
\text { bone parameters in the distal femur metaphysieal } \\
\text { regions and the lumbar vertebrae in male mice } \\
\text { L. reuteri } 6475 \text { treatment had no effect } \\
\text { on bone parameters in female mice }\end{array}$ & $\begin{array}{l}\text { McCabe et } \\
\text { al., } 2013\end{array}$ \\
\hline $\begin{array}{l}\text { Balb/c mice } \\
\text { Female OVX }\end{array}$ & $\begin{array}{l}\text { Treated with Lactobacillus } \\
\text { reuteri ATCC PTA } 6475\end{array}$ & $\begin{array}{l}\text { L. reuteri treatment protected } \\
\text { OVX mice from bone loss } \\
\text { L. reuteri treatment decreased osteoclastogenesis }\end{array}$ & $\begin{array}{l}\text { Britton et } \\
\text { al., } 2014\end{array}$ \\
\hline $\begin{array}{l}\text { B57BL/6N mice } \\
\text { Female OVX }\end{array}$ & $\begin{array}{l}\text { Treated with 1) Lactobacillus paracasei } \\
\text { DSM13423; } 2 \text { ) a mixture of } L \text {. } \\
\text { paracasei DSM13434, L. plantarum } \\
\text { DSM } 15312 \text { and DSM } 15313\end{array}$ & $\begin{array}{l}\text { L. paracasei DSM } 13423 \text { and the mixture } \\
\text { treatment protected from OVX-induced } \\
\text { cortical bone loss and bone resorption }\end{array}$ & $\begin{array}{l}\text { Ohlsson et } \\
\text { al., } 2014\end{array}$ \\
\hline $\begin{array}{l}\text { Balb/c mice } \\
\quad \text { Female with mild } \\
\text { inflammatory state } \\
\text { induced by dorsal } \\
\text { surgical incision (DSI) }\end{array}$ & $\begin{array}{l}\text { Orally supplemented with } \\
\text { L. reuteri PTA } 6457\end{array}$ & $\begin{array}{l}\text { L. eruteri } 6457 \text { treatment increased bone density } \\
\text { in females but only in those that underwent DSI }\end{array}$ & $\begin{array}{l}\text { Collins et } \\
\text { al., } 2016\end{array}$ \\
\hline $\begin{array}{l}\text { BALB/c mice } \\
\text { Male germ-free }\end{array}$ & $\begin{array}{l}\text { Lactobacillus. Plantarum }{ }^{\mathrm{WJ}} \text { and } \\
\text { L. plantarum }{ }^{\mathrm{NIZO}} 877 \text { were gavage } \\
\text { to } 8 \text {-week-old mice to develop } \\
\text { Lactobacillus-monocolonized mice }\end{array}$ & $\begin{array}{l}\text { Reduced femur length, cortical thickness, } \\
\text { cortical bone fraction, and the trabecular } \\
\text { fraction of the femur in germ-free mice } \\
\text { Lactobacilli promoted juvenile growth }\end{array}$ & $\begin{array}{l}\text { Schwarzer } \\
\text { et al., } 2016\end{array}$ \\
\hline $\begin{array}{l}\text { C57BL6/J mice } \\
\text { Female germ-free }\end{array}$ & $\begin{array}{l}\text { Sex steroid deficiency mice treated with } \\
\text { Lactobacillus rhamnosus GG, commercial } \\
\text { probiotic supplement VSL\#3, Escherichia } \\
\text { coli and a mutant L. rhamnosus GG }\end{array}$ & $\begin{array}{l}\text { Probiotic treatment reduced bone marrow } \\
\text { inflammation and protected against bone loss } \\
\text { nonprobiotic ( } E \text {. coli and mutant } L \text {. rhamnosus } \\
\text { GG) treatment showed no protective effect }\end{array}$ & $\begin{array}{l}\text { Li et al., } \\
2016\end{array}$ \\
\hline \multicolumn{4}{|l|}{ Prebiotics } \\
\hline $\begin{array}{l}\text { Wistar rat } \\
\quad \text { Female } \\
\text { ovariectomized (OVX) }\end{array}$ & Treated with galactooligosaccharides (GOS) & $\begin{array}{l}\text { GOS treatment absorbed calcium more efficiently } \\
\text { GOS showed higher bone (femur and tibia) ash } \\
\text { weight and tibia calcium context of OVX rats }\end{array}$ & $\begin{array}{l}\text { Chonan et } \\
\text { al., } 1995\end{array}$ \\
\hline $\begin{array}{l}\text { Wistar rat } \\
\text { Male rat }\end{array}$ & Treated with inulin and resistant starch & $\begin{array}{l}\text { Inulin and resistant starch increased the intestinal } \\
\text { absorption and balance of } \mathrm{Ca} \text { and } \mathrm{Mg} \text {, without } \\
\text { altering the plasma level of } \mathrm{Ca} \text { and } \mathrm{Mg}\end{array}$ & $\begin{array}{l}\text { Younes et } \\
\text { al., } 2001\end{array}$ \\
\hline $\begin{array}{c}\text { Sprague Dawley rat } \\
\text { Female OVX }\end{array}$ & $\begin{array}{l}\text { Treated with inulin and } \\
\text { fructooligosaccharides (FOS) }\end{array}$ & $\begin{array}{l}\text { Inulin and FOS treatment increased bone mineral } \\
\text { density, breaking strength, and total calcium } \\
\text { Inulin and FOS treatment inhibited } \\
\text { the bone resorption }\end{array}$ & $\begin{array}{l}\text { Zafar et } \\
\text { al., } 2004\end{array}$ \\
\hline $\begin{array}{l}\text { Sprague Dawley rat } \\
\text { Male rat }\end{array}$ & $\begin{array}{l}\text { Treated with inulin-type fructans (inulin, } \\
\text { oligofructose, fructooligosaccharides) }\end{array}$ & $\begin{array}{l}\text { Inulin-type fructans increased mineral } \\
\text { absorption, retention and accumulation } \\
\text { in bone in the case of } \mathrm{Ca}, \mathrm{Mg} \text { and } \mathrm{Zn}\end{array}$ & $\begin{array}{l}\text { Raschka and } \\
\text { Daniel, } 2005\end{array}$ \\
\hline $\begin{array}{c}\text { Sprague Dawley rats } \\
\text { Female OVX }\end{array}$ & $\begin{array}{l}\text { Treated with vitamin D-deficient diet with } \\
\text { or without difructose anhydride III (DFAIII) }\end{array}$ & $\begin{array}{l}\text { Vitamin D deficiency decreased Ca } \\
\text { absorption and bone mineralization } \\
\text { DFAlll treatment restored the reduction } \\
\text { of Ca absorption and femoral Ca }\end{array}$ & $\begin{array}{l}\text { Mitamura } \\
\text { and Hara, } \\
2006\end{array}$ \\
\hline $\begin{array}{r}\text { BALB/c mice } \\
\text { Female }\end{array}$ & $\begin{array}{l}\text { Treated with antibiotics and } \\
\text { short chain fatty acid (SCFA) }\end{array}$ & $\begin{array}{l}\text { Antibiotic treatment decreased serum } \\
\text { IGF-1 and inhibited bone formation } \\
\text { Antibiotic treatment group supplemented } \\
\text { with SCFA restored IGF-1 and bone mass }\end{array}$ & $\begin{array}{l}\text { Yan et al., } \\
2016\end{array}$ \\
\hline $\begin{array}{l}\text { Human } \\
\text { Postmenopausal } \\
\text { women }\end{array}$ & Supplemented with inulin & $\begin{array}{l}\text { Inulin treatment improved mineral } \\
\text { absorption and impacted bone turnover }\end{array}$ & $\begin{array}{l}\text { Holloway et } \\
\text { al., } 2007\end{array}$ \\
\hline $\begin{array}{l}\text { Human } \\
\text { Postmenopausal } \\
\text { women }\end{array}$ & $\begin{array}{l}\text { Treated with 1) milk fermented with } \\
\text { Lactobacillus helveticus LBK-16H bacteria, } \\
\text { supplemented with } 14.5 \mathrm{mg} / 100 \mathrm{~g} \\
\text { of IPP and VPP; } 2 \text { ) normal sour milk } \\
\text { fermented with a Lactococcus sp. } \\
\text { Mixed culture; } 3 \text { ) orange juice with } \\
14.5 \mathrm{mg} / 100 \mathrm{~g} \text { of IPP and VPP; } 4 \text { ) orange } \\
\text { juice with calcium lactate gluconate }\end{array}$ & $\begin{array}{l}\text { L. helveticus fermented milk treatment reduced } \\
\text { serum PTH and increased serum calcium }\end{array}$ & $\begin{array}{l}\text { Narva et } \\
\text { al., 2004b }\end{array}$ \\
\hline
\end{tabular}


2007). However, no effect was reported in adolescent girls supplemented with inulin (Martin et al., 2010). The conflicting results may be attributed to the variation in treatment conditions, intervention duration, and lack of controlled diets, host genetics, baseline bone status, and participant age.

Our current knowledge related to the microbiota's role on prebiotic-bone mechanisms remains limited, but evaluation of gut microbiota profiles may provide further insights. GOS treatment resulted in dose-dependent differences in gut microbial communities, and quantitative PCR measures suggested that GOS increased the prevalence of bifidobacteria (Whisner et al., 2013). In addition to the direct influence on gut microbiota composition, the most prominent theory to explain prebiotic effects on bone is that prebiotic fibers resist digestion in the small intestine and upon reaching the colon are fermented into short chain fatty acids (SCFAs). SCFAs have the ability to prevent calcium from complexing with other compounds, therefore increase the calcium absorption (Whisner and Weaver, 2017). Several animal studies have proven that treatment with SCFAs significantly increases bone mass and prevents postmenopausal and inflammation-induced bone loss (Lucas et al., 2018; Yan et al., 2016). Meanwhile, an increase in SCFAs has been shown in the supplementation with high-fibre diet, such as inulintype fructans (Raschka and Daniel, 2005), resistant starch (Younes et al., 2001) and GOS (Chonan et al., 1995). However, most previous human trails have only evaluated the calcium absorption upon SCFAs treatment, but not bone quality. Thus, direct evidence on bone quality should be performed in future study to understand the effect of SCFAs on bone health.

\section{Conclusion}

The study of gut microbiota on bone health and development of probiotics/prebiotics as new osteoporosis treatment approach is a rapidly growing area of investigation. There are many studies that support the role of gut microbiota in the regulation of bone health, as well as the potential of probiotics/prebiotics on osteoporosis prevention, despite the fact that underlying mechanisms still remain unclear. Currently, it has been well accepted that gut microbiota can regulate bone metabolism via immune system and endocrine system as well as mineral absorption. Meanwhile, dietary consumption of probiotics and prebiotics could mediate the gut environment and stimulate the related mechanism to facilitate the production of signaling molecules, immune cells, and metabolites, and therefore beneficially influence bone health. To date, the most well studied probiotics are lactobacillus and bifidobacterium. Although most of the treatments were in animal trials, the supplementation of lactobacillus and bifidobacterium showed effects on improving bone quality and preventing bone loss. Meanwhile, the consumption of prebiotics, such as disaccharide, oligosaccharide and polysaccharide, alters the gut microbial content and also contributes to bone health. However, there is still a controversy with regard to the efficacy of probiotics and prebiotics supplementation in human studies. Therefore, further studies are warranted to better understand the effects of the variations (age, gender, dose, methods of delivery, duration of treatment, and others) on the change of gut microbiota and its resultant bone health status.

\section{References}

Al-Asmakh, M., and Zadjali, F. (2015). Use of Germ-Free Animal Models in Microbiota-Related Research. J. Microbiol. Biotechnol. 25(10):
1583-1588. doi:10.4014/jmb.1501.01039.

Baker, J.M., Al-Nakkash, L., and Herbst-Kralovetz, M.M. (2017). Estrogengut microbiome axis: Physiological and clinical implications. Maturitas 103: 45-53. doi:10.1016/J.MATURITAS.2017.06.025.

Blanton, L.V., Charbonneau, M.R., Salih, T., Barratt, M.J., Venkatesh, S., IIkaveya, O., and Gordon, J.I. (2016). Gut bacteria that prevent growth impairments transmitted by microbiota from malnourished children. Science 351(6275): aad3311-aad3311. doi:10.1126/science. aad3311.

Bora, S.A., Kennett, M.J., Smith, P.B., Patterson, A.D., and Cantorna, M.T. (2018). The Gut Microbiota Regulates Endocrine Vitamin D Metabolism through Fibroblast Growth Factor 23. Frontiers Immunol. 9: 408. doi:10.3389/fimmu.2018.00408.

Britton, R.A., Irwin, R., Quach, D., Schaefer, L., Zhang, J., Lee, T., and McCabe, L.R. (2014). Probiotic L. reuteri Treatment Prevents Bone Loss in a Menopausal Ovariectomized Mouse Model. J. Cellular Physiol. 229(11): 1822-1830. doi:10.1002/jcp.24636.

Chen, Y.C., Greenbaum, J., Shen, H., and Deng, H.W. (2017). Association Between Gut Microbiota and Bone Health: Potential Mechanisms and Prospective. The J. Clin. Endocrinol. Metabol. 102(10): 36353646. doi:10.1210/jc.2017-00513.

Chiang, S.S., and Pan, T.M. (2011). Antiosteoporotic Effects of Lactobacillus -Fermented Soy Skim Milk on Bone Mineral Density and the Microstructure of Femoral Bone in Ovariectomized Mice. J. Agric. Food Chem. 59(14): 7734-7742. doi:10.1021/jf2013716.

Chonan, O., Matsumoto, K., and Watanuki, M. (1995). Effect of Galactooligosaccharides on Calcium Absorption and Preventing Bone Loss in Ovariectomized Rats. Biosci. Biotechnol. Biochem. 59(2): 236-239. doi:10.1271/bbb.59.236.

Collins, F.L., Irwin, R., Bierhalter, H., Schepper, J., Britton, R.A., Parameswaran, N., and McCabe, L.R. (2016). Lactobacillus reuteri 6475 Increases Bone Density in Intact Females Only under an Inflammatory Setting. PLOS ONE 11(4): e0153180. doi:10.1371/journal. pone. 0153180

Collins, F.L., Rios-Arce, N.D., Schepper, J.D., Parameswaran, N., and McCabe, L.R. (2017). The Potential of Probiotics as a Therapy for Osteoporosis. Microbiol. Spect. 5(4): doi:10.1128/microbiolspec.BAD0015-2016.

Cox, L.M., Yamanishi, S., Sohn, J., Alekseyenko, A.V., Leung, J.M., Cho, I., and Blaser, M.J. (2014). Altering the intestinal microbiota during a critical developmental window has lasting metabolic consequences. Cell 158(4): 705-721. doi:10.1016/j.cell.2014.05.052.

Crotti, T.N., Dharmapatni, A.A.S.S.K., Alias, E., and Haynes, D.R. (2015). Osteoimmunology: Major and Costimulatory Pathway Expression Associated with Chronic Inflammatory Induced Bone Loss. J. Immunol. Res. 2015: 1-13. doi:10.1155/2015/281287.

Cui, Y., Niziolek, P.J., MacDonald, B.T., Zylstra, C.R., Alenina, N., Robinson, D.R., and Robling, A.G. (2011). Lrp5 functions in bone to regulate bone mass. Nature Med. 17(6): 684-691. doi:10.1038/nm.2388.

Di Stefano, M., Veneto, G., Malservisi, S., and Corazza, G.R. (2001). Small Intestine Bacterial Overgrowth and Metabolic Bone Disease. Digest. Diseases Sci. 46(5): 1077-1082. doi:10.1023/A:1010722314493.

García-Vieyra, M.I., Del Real, A., and López, M.G. (2014). Agave Fructans: Their Effect on Mineral Absorption and Bone Mineral Content. J. Med. Food 17(11): 1247-1255. doi:10.1089/jmf.2013.0137.

Geuking, M.B., Köller, Y., Rupp, S., and McCoy, K.D. (2014). The interplay between the gut microbiota and the immune system. Gut Microbes 5(3): 411-418. doi:10.4161/gmic.29330.

Giustina, A., Mazziotti, G., and Canalis, E. (2008). Growth Hormone, Insulin-Like Growth Factors, and the Skeleton. Endocrine Rev. 29(5): 535-559. doi:10.1210/er.2007-0036.

Guadamuro, L., Delgado, S., Redruello, B., Flórez, A.B., Suárez, A., Martínez-Camblor, P., and Mayo, B. (2015). Equol status and changes in fecal microbiota in menopausal women receiving long-term treatment for menopause symptoms with a soy-isoflavone concentrate. Frontiers Microbiol. 6: 777. doi:10.3389/fmicb.2015.00777.

Guss, J.D., Horsfield, M.W., Fontenele, F.F., Sandoval, T.N., Luna, M., Apoorva, F., and Hernandez, C.J. (2017). Alterations to the Gut Microbiome Impair Bone Strength and Tissue Material Properties. J. Bone Mineral Res. 32(6): 1343-1353. doi:10.1002/jbmr.3114.

Hicks, P.D., Hawthorne, K.M., Berseth, C.L., Marunycz, J.D., Heubi, J.E., and 
Abrams, S.A. (2012). Total calcium absorption is similar from infant formulas with and without prebiotics and exceeds that in human milk-fed infants. BMC Pediatr. 12(1): 613. doi:10.1186/1471-2431$12-118$.

Holloway, L., Moynihan, S., Abrams, S.A., Kent, K., Hsu, A.R., and Friedlander, A.L. (2007). Effects of oligofructose-enriched inulin on intestinal absorption of calcium and magnesium and bone turnover markers in postmenopausal women. Br. J. Nutr. 97(02): 365. doi:10.1017/ S000711450733674X.

Imai, Y., Youn, M.Y., Kondoh, S., Nakamura, T., Kouzmenko, A., Matsumoto, T., and Kato, S. (2009). Estrogens Maintain Bone Mass by Regulating Expression of Genes Controlling Function and Life Span in Mature Osteoclasts. Ann. NY Acad.Sci. 1173: E31-E39. doi:10.1111/j.17496632.2009.04954.x

Keller, J., and Schinke, T. (2013). The role of the gastrointestinal tract in calcium homeostasis and bone remodeling. Osteopor. Int. 24(11): 2737-2748. doi:10.1007/s00198-013-2335-4.

Kim, N., Takami, M., Rho, J., Josien, R., and Choi, Y. (2002). A novel member of the leukocyte receptor complex regulates osteoclast differentiation. J. Exper. Med. 195(2): 201-209. pmid:11805147.

Kim, Y., Jang, K., Lee, E., Cho, Y., Kang, S., Ha, W., and Choue, R. (2004). The effect of chicory fructan fiber on calcium absorption and bone metabolism in Korean postmenopausal women. Nutr. Sci. 7(3): 151157. Retrieved from http://www.dbpia.co.kr/Journal/ArticleDetail/ NODE01626268.

Kini, U., and Nandeesh, B.N. (2012). Physiology of Bone Formation, Remodeling, and Metabolism. Radionuclide and Hybrid Bone Imaging Springer, Berlin, Heidelberg, 29-57. doi:10.1007/978-3-642-024009.

Kruger, M.C., Chan, Y.M., Kuhn-Sherlock, B., Lau, L.T., Lau, C., Chin, Y.S., and Schollum, L.M. (2016). Differential effects of calcium- and vitamin D-fortified milk with FOS-inulin compared to regular milk, on bone biomarkers in Chinese pre- and postmenopausal women. Eur. J. Nutr. 55(5): 1911-1921. doi:10.1007/s00394-015-1007-x.

Kwa, M., Plottel, C.S., Blaser, M.J., and Adams, S. (2016). The Intestinal Microbiome and Estrogen Receptor-Positive Female Breast Cancer. J. Natl. Cancer Inst. 108(8): djw029. doi:10.1093/jnci/djw029.

Leder, B. (2007). Gonadal steroids and bone metabolism in men. Curr. Opin. Endocrinol Diabetes Obes. 14(3): 241-246. doi:10.1097/ MED.0b013e32814db87b.

Legette, L.L., Lee, W., Martin, B.R., Story, J.A., Campbell, J.K., and Weaver, C.M. (2012). Prebiotics Enhance Magnesium Absorption and Inulinbased Fibers Exert Chronic Effects on Calcium Utilization in a Postmenopausal Rodent Model. J. Food Sci. 77(4): 88-94. doi:10.1111/ j.1750-3841.2011.02612.x.

Li, J.Y., Chassaing, B., Tyagi, A.M., Vaccaro, C., Luo, T., Adams, J., and Pacifici, R. (2016). Sex steroid deficiency-associated bone loss is microbiota dependent and prevented by probiotics. J. Clin. Invest. 126(6): 2049-2063. doi:10.1172/JCl86062.

Lombardi, G., Di Somma, C., Rubino, M., Faggiano, A., Vuolo, L., Guerra, E., and Colao, A. (2011). The roles of parathyroid hormone in bone remodeling: prospects for novel therapeutics. J. Endocrinol. Invest. 34(7 Suppl): 18-22. pmid:21985975.

Lorenzo, J., Horowitz, M., and Choi, Y. (2008). Osteoimmunology: interactions of the bone and immune system. Endocr. Rev. 29(4): 403-440. doi:10.1210/er.2007-0038.

Lucas, S., Omata, Y., Hofmann, J., Böttcher, M., Iljazovic, A., Sarter, K., and Zaiss, M.M. (2018). Short-chain fatty acids regulate systemic bone mass and protect from pathological bone loss. Nat. Commun. 9(1): 55. doi:10.1038/s41467-017-02490-4.

Martin, B.R., Braun, M.M., Wigertz, K., Bryant, R., Zhao, Y., Lee, W., and Weaver, C.M. (2010). Fructo-oligosaccharides and calcium absorption and retention in adolescent girls. J. Am. Coll. Nutr. 29(4): 382386. pmid:21041813.

McCabe, L.R., Irwin, R., Schaefer, L., and Britton, R.A. (2013). Probiotic use decreases intestinal inflammation and increases bone density in healthy male but not female mice. J. Cell. Physiol. 228(8): 17931798. doi:10.1002/jcp.24340.

Menagh, P.J., Turner, R.T., Jump, D.B., Wong, C.P., Lowry, M.B., Yakar, S., and Iwaniec, U.T. (2010). Growth hormone regulates the balance between bone formation and bone marrow adiposity. J. Bone Miner.
Res. 25(4): 757-768. doi:10.1359/jbmr.091015.

Mitamura, R., and Hara, H. (2006). Ingestion of difructose anhydride III partially restores calcium absorption impaired by vitamin $\mathrm{D}$ and estrogen deficiency in rats. Eur. J. Nutr. 45(4): 242-249. doi:10.1007/ s00394-006-0592-0.

Mitsui, T., Shimaoka, K., Takagi, C., Goto, Y., Kagami, H., and Ito, A. (2005). Small bowel bacterial overgrowth may not affect bone mineral density in older people. Clin. Nutri. 24(6): 920-924. doi:10.1016/J. CLNU.2005.05.022.

Mödder, U.I., Achenbach, S.J., Amin, S., Riggs, B.L., Melton, L.J., Khosla, S., and Khosla, S. (2010). Relation of serum serotonin levels to bone density and structural parameters in women. J. Bone Miner. Res. 25(2): 415-422. doi:10.1359/jbmr.090721.

Morris, H.A., O'Loughlin, P.D., and Anderson, P.H. (2010). Experimental Evidence for the Effects of Calcium and Vitamin D on Bone: A Review. Nutrients 2(9): 1026-1035. doi:10.3390/nu2091026.

Narva, M., Collin, M., Lamberg-Allardt, C., Kärkkäinen, M., Poussa, T., Vapaatalo, H., and Korpela, R. (2004a). Effects of long-term intervention with Lactobacillus helveticus-fermented milk on bone mineral density and bone mineral content in growing rats. Ann. Nutr. Metab. 48(4): 228-234. doi:10.1159/000080455.

Narva, M., Nevala, R., Poussa, T., and Korpela, R. (2004b). The effect of Lactobacillus helveticus fermented milk on acute changes in calcium metabolism in postmenopausal women. Eur. J. Nutr. 43(2): 61-68. doi:10.1007/s00394-004-0441-y.

Neuman, H., Debelius, J.W., Knight, R., and Koren, O. (2015). Microbial endocrinology: the interplay between the microbiota and the endocrine system. FEMS Microbiol. Rev. 39(4): 509-521. doi:10.1093/ femsre/fuu 010 .

Nieves, J.W. (2005). Osteoporosis: the role of micronutrients. Am. J. Clin. Nutr. 81(5): 1232S-1239S. pmid:15883457.

Nilsson, A., Swolin, D., Enerback, S., and Ohlsson, C. (1995). Expression of functional growth hormone receptors in cultured human osteoblastlike cells. J. Clin. Endocrinol. Metab. 80(12): 3483-3488. doi:10.1210/ jcem.80.12.8530587.

Nobel, Y.R., Cox, L.M., Kirigin, F.F., Bokulich, N.A., Yamanishi, S., Teitler, I., and Blaser, M.J. (2015). Metabolic and metagenomic outcomes from early-life pulsed antibiotic treatment. Nat. Commun. 6(1): 7486. doi:10.1038/ncomms8486.

Office of the Surgeon General (US). (2004). Bone Health and Osteoporosis A Report of the Surgeon General. Rockville (MD). Retrieved from https://www.ncbi.nlm.nih.gov/books/NBK45513/pdf/Bookshelf NBK45513.pdf.

Ohlsson, C., Engdahl, C., Fåk, F., Andersson, A., Windahl, S.H., Farman, H.H., and Sjögren, K. (2014). Probiotics Protect Mice from Ovariectomy-Induced Cortical Bone Loss. PLoS ONE 9(3): e92368. doi:10.1371/ journal.pone.0092368.

Olney, R.C. (2003). Regulation of bone mass by growth hormone. Medical and Pediatric Oncology 41(3): 228-234. doi:10.1002/mpo.10342.

Palm, N.W., de Zoete, M.R., and Flavell, R.A. (2015). Immune-microbiota interactions in health and disease. Clin. Immunol. 159(2): 122-127. doi:10.1016/j.clim.2015.05.014.

Quach, D., and Britton, R.A. (2017). Gut Microbiota and Bone Health. Adv. Exp. Med. Biol. 1033: 47-58. doi:10.1007/978-3-319-66653-2_4.

Quach, D., Collins, F., Parameswaran, N., McCabe, L., and Britton, R.A. (2018). Microbiota Reconstitution Does Not Cause Bone Loss in GermFree Mice. mSphere 3(1): doi:10.1128/mSphereDirect.00545-17.

Raschka, L., and Daniel, H. (2005). Diet composition and age determine the effects of inulin-type fructans on intestinal calcium absorption in rat. Eur. J. Nutr. 44(6): 360-364. doi:10.1007/s00394-004-0535-6.

Roberfroid, M.B., Cumps, J., and Devogelaer, J.P. (2002). Dietary Chicory Inulin Increases Whole-Body Bone Mineral Density in Growing Male Rats. J. Nutr. 132(12): 3599-3602. doi:10.1093/jn/132.12.3599.

Rucci, N. (2008). Molecular biology of bone remodelling. Clin. Cases Miner. Bone Metab. 5: 49-56. Retrieved from http://www.pubmedcentral. nih.gov/articlerender.fcgi $?$ artid=2781193\&tool=pmcentrez\&rendert ype=abstract.

Salari Sharif, P., Abdollahi, M., and Larijani, B. (2011). Current, new and future treatments of osteoporosis. Rheumatol. Int. 31(3): 289-300. doi:10.1007/s00296-010-1586-z.

Schepper, J.D., Irwin, R., Kang, J., Dagenais, K., Lemon, T., Shinouskis, A., 
and McCabe, L.R. (2017). Probiotics in Gut-Bone Signaling. Adv. Exp. Med. Biol. 1033: 225-247. doi:10.1007/978-3-319-66653-2 11.

Scholz-Ahrens, K.E., Ade, P., Marten, B., Weber, P., Timm, W., Açil, Y., and Schrezenmeir, J. (2007). Prebiotics, Probiotics, and Synbiotics Affect Mineral Absorption, Bone Mineral Content, and Bone Structure. J. Nutr. 137(3): 838S-846S. doi:10.1093/jn/137.3.838S.

Schwarzer, M., Makki, K., Storelli, G., Machuca-Gayet, I., Srutkova, D., Hermanova, P., and Leulier, F. (2016). Lactobacillus plantarum strain maintains growth of infant mice during chronic undernutrition. Science 351(6275): 854-857. doi:10.1126/science.aad8588.

Sheikh, M.S., Schiller, L.R., and Fordtran, J.S. (1990). In vivo intestinal absorption of calcium in humans. Miner. Electrolyte. Metab. 16(2-3): 130-146. pmid:2250619.

Sjögren, K., Engdahl, C., Henning, P., Lerner, U.H., Tremaroli, V., Lagerquist, M.K., and Ohlsson, C. (2012). The gut microbiota regulates bone mass in mice. J. Bone Miner. Res. 27(6): 1357-1367. doi:10.1002/ jbmr.1588.

Stotzer, P.O., Johansson, C., Mellström, D., Lindstedt, G., and Kilander, A.F. (2003). Bone mineral density in patients with small intestinal bacterial overgrowth. Hepato-Gastroenterology 50(53): 1415-1418. pmid:14571751.

Sudo, N. (2014). Microbiome, HPA Axis and Production of Endocrine Hormones in the Gut. Adv. Exp. Med. Bio. 817: 77-194. doi:10.1007/9781-4939-0897-4_8.

Sunyecz, J.A. (2008). The use of calcium and vitamin D in the management of osteoporosis. Ther. Clin. Risk Manag. 4(4): 827-836. pmid:19209265.

Syed, F., and Khosla, S. (2005). Mechanisms of sex steroid effects on bone. Biochem. Biophys. Res. Commun. 328(3): 688-696. doi:10.1016/j. bbrc.2004.11.097.

Teitelbaum, S.L. (2000). Bone resorption by osteoclasts. Science 289(5484): 1504-1508. pmid:10968780.

US Department of Health and Human Services. (2004). Bone health and osteoporosis: a report of the Surgeon General. US Health and Human Services.

van den Heuvel, E.G.H.M., Schoterman, M.H.C., and Muijs, T. (2000). Transgalactooligosaccharides Stimulate Calcium Absorption in Postmenopausal Women. J. Nutr. 130(12): 2938-2942. doi:10.1093/ jn/130.12.2938.

Vázquez, L., Flórez, A.B., Guadamuro, L., and Mayo, B. (2017). Effect of Soy Isoflavones on Growth of Representative Bacterial Species from the Human Gut. Nutrients 9(7): E727. doi:10.3390/nu9070727.

Walsh, M.C., Kim, N., Kadono, Y., Rho, J., Lee, S.Y., Lorenzo, J., and Choi, Y. (2006). Osteoimmunology: Interplay Between the Immune System and Bone Metabolism. Annu. Rev. Immunol. 24(1): 33-63. doi:10.1146/annurev.immunol.24.021605.090646.

Wang, Y., Bikle, D.D., and Chang, W. (2013). Autocrine and Paracrine Actions of IGF-I Signaling in Skeletal Development. Bone Research 1(3): 249-259. doi:10.4248/BR201303003.

Wang, Y., Nishida, S., Sakata, T., Elalieh, H.Z., Chang, W., Halloran, B.P., and Bikle, D.D. (2006). Insulin-Like Growth Factor-I Is Essential for Embryonic Bone Development. Endocrinology 147(10): 4753-4761. doi:10.1210/en.2006-0196.

Whisner, C.M., Martin, B.R., Schoterman, M.H.C., Nakatsu, C.H., McCabe, L.D., McCabe, G.P., and Weaver, C.M. (2013). Galacto-oligosaccharides increase calcium absorption and gut bifidobacteria in young girls: a double-blind cross-over trial. Br. J. Nutr. 110(07): 1292-1303. doi:10.1017/S000711451300055X.

Whisner, C.M., and Weaver, C.M. (2017). Prebiotics and Bone. Adv. Exp. Med. Biol. 1033: 201-224. doi:10.1007/978-3-319-66653-2_10.

Wu, H.J., Ivanov, I.I., Darce, J., Hattori, K., Shima, T., Umesaki, Y., and Mathis, D. (2010). Gut-residing segmented filamentous bacteria drive autoimmune arthritis via Thelper 17 cells. Immunity 32(6): 815-827. doi:10.1016/j.immuni.2010.06.001.

$\mathrm{Wu}, \mathrm{H} . J$., and Wu, E. (2012). The role of gut microbiota in immune homeostasis and autoimmunity. Gut Microbes 3(1): 4-14. doi:10.4161/ gmic.19320.

Wu, S., Yang, W., and De Luca, F. (2015). Insulin-Like Growth Factor-Independent Effects of Growth Hormone on Growth Plate Chondrogenesis and Longitudinal Bone Growth. Endocrinology 156(7): 25412551. doi:10.1210/en.2014-1983.

Wüster, C. (2000). Fracture Rates in Patients with Growth Hormone Deficiency. Horm. Res. Paediatr. 54(1): 31-35. doi:10.1159/000063445.

Xu, X., Harris, K.S., Wang, H.J., Murphy, P.A., and Hendrich, S. (1995). Bioavailability of Soybean Isoflavones Depends upon Gut Microflora in Women. J. Nutr. 125(9): 2307-2315. doi:10.1093/jn/125.9.2307.

Xu, X., Jia, X., Mo, L., Liu, C., Zheng, L., Yuan, Q., and Zhou, X. (2017). Intestinal microbiota: a potential target for the treatment of postmenopausal osteoporosis. Bone Res. 5: 17046. doi:10.1038/boneres.2017.46.

Yadav, V.K., Ryu, J.H., Suda, N., Tanaka, K.F., Gingrich, J.A., Schütz, G., and Karsenty, G. (2008). Lrp5 Controls Bone Formation by Inhibiting Serotonin Synthesis in the Duodenum. Cell 135(5): 825-837. doi:10.1016/j.cell.2008.09.059.

Yan, J., and Charles, J.F. (2018). Gut Microbiota and IGF-1. Calcified Tissue Int. 102(4): 406-414. doi:10.1007/s00223-018-0395-3.

Yan, J., Herzog, J.W., Tsang, K., Brennan, C.A., Bower, M.A., Garrett, W.S., and Charles, J.F. (2016). Gut microbiota induce IGF-1 and promote bone formation and growth. Proc. Natl. Acad. Sci. 113(47): E7554E7563. doi:10.1073/pnas.1607235113.

Yano, J.M., Yu, K., Donaldson, G.P., Shastri, G.G., Ann, P., Ma, L., and Hsiao, E.Y. (2015). Indigenous bacteria from the gut microbiota regulate host serotonin biosynthesis. Cell 161(2): 264-276. doi:10.1016/j. cell.2015.02.047.

Yap, K.W., Mohamed, S., Yazid, A.M., Maznah, I., and Meyer, D.M. (2005). Dose-response effects of inulin on the faecal short-chain fatty acids content and mineral absorption of formula-fed infants. Nutrition \& Food Science 35(4): 208-219. doi:10.1108/00346650510605603.

Younes, H., Coudray, C., Bellanger, J., Demigné, C., Rayssiguier, Y., and Rémésy, C. (2001). Effects of two fermentable carbohydrates (inulin and resistant starch) and their combination on calcium and magnesium balance in rats. Br. J. Nutr. 86(4): 479-485. pmid:11591235.

Yuan, J.P., Wang, J.H., and Liu, X. (2007). Metabolism of dietary soy isoflavones to equol by human intestinal microflora - implications for health. Mol. Nutr. Food Res. 51(7): 765-781. doi:10.1002/ mnfr.200600262.

Zafar, T.A., Weaver, C.M., Zhao, Y., Martin, B.R., and Wastney, M.E. (2004). Nondigestible Oligosaccharides Increase Calcium Absorption and Suppress Bone Resorption in Ovariectomized Rats. J. Nutr. 134(2): 399-402. doi:10.1093/jn/134.2.399.

Zupan, J., Jeras, M., and Marc, J. (2013). Osteoimmunology and the influence of pro-inflammatory cytokines on osteoclasts. Biochem. Med. 23(1): 43-63. pmid:23457765. 